\title{
An Universal Struggle: Advocating the Animals' Ignored Rights
}

\author{
Esra Çelebi Zengin ${ }^{1}$
}

\begin{abstract}
The concept of 'right' differs from country to country in terms of its limitations; however, there are several rights which have the characteristics of immunity all over the world. When assessed in this context, there are fundamental rights of which violation are considered to be crimes against humanity such as the right to life and the right not to be tortured. Nevertheless, it is seen that universal principles in crime have not become valid since the victim of violations in question are the animal but not the people. Considering this reality, approaches proposed to animals which form one of the weakest rings of life and their rights need to be examined within the context of the birth and development of the animal rights movement. But, it is still known that some countries and sectors should cover a lot of ground in protection of animal rights, although a tough struggle has been given in the historical process. In the matter of improving this though processes by which animal have had unrecoverable damage, policymakers and individuals have great responsibility. This article, which details the major areas in which animal rights have been violated, was written in order to raise awareness of the animal's living conditions, its impact on ecology and the sanctity of its right to life.
\end{abstract}

Keywords: animal rights, animal rights violations, ecology, local governments.

\section{Introduction}

A process which included "inhuman" approaches and practices was experienced until the period before the concept of rights was adopted for animals. Within this scope, the idea that animals are nothing more than robots without the ability to think or feel was put forward in $17^{\text {th }}$ century and René Descartes, who is regarded as the founder of the modern philosophy, defended the idea that the animals, which he refers to as "automatic or moving machines", don't have a spirit which the God has bestowed only on human beings. Descartes and his followers nailed the claws of animals on the wood and injured them in every way you might imagine by slashing their bodies and considered the reactions of the animals that were racked with pain as unlike from a sound of $a$ malfunctioning machine and a creaking wheel that needs to be lubricated. The German philosopher I. Kant in $18^{\text {th }}$ century accepted that animals can suffer, but considered them as merely an instrument of human purpose and did not ignore that someone who is cruel to animals might take a stern attitude towards people (Francione, 2008:51-52).

Of course, in the centuries when these views dominated, the approach to animals in the midst of infinite suffering could not be changed in terms of legal, conscientious, or scientific aspects, and the emergence of approaches pioneering in today's challenges traced to the 19th century. 


\section{Basic Approaches to Animal Rights}

When the literature on animal rights is searched, we come across the first opinion which is representative of the departure from the Middle Ages is the idea of indirect duty. The idea of an indirect duty that specifies that moral obligations are not against animals but they are against their owners, has given animals protection only to the extent of human concerns and property interests. According to this opinion, animals are not living beings with rights; they are regarded only as a property only belonging to buman being (Tuna, 1991: 72-73). This approach to animals has reflected in legal regulations. In fact, within this context, taking into account the provisions of law in force in Turkey, it is worth pointing out that injuring an animal is evaluated within the scope of "causing damage to property"

According to the opinion of the convention on animal rights, the people who form a society accept the moral system or ethic which will be valid by making a convention between each other. Animals, on the other hand, are deprived of the rights arising from the convention since they cannot have the ability to understand the concept of the convention. It comes into question that animals benefit from moral rules indirectly only through the rights of people who are emotionally bound to the animal they feed. According to this opinion, which addresses to the emotions of humans, if what happens to an experimental animal is not interested in anybody, this animal can suffer any kind of pain, and if it does not harm a human being, it is regarded as not a wrong situation on moral grounds (Tuna, 1991: 72-73).

In respect of the utilitarianism theory used to defend animal rights, all living things have similar interests. Whoever they are, black or white, female or male, human or animal, all want to ease the pain and to find happiness. The interests of each are equally important (Tuna, 1991: 75). This humane treatment principle is originated from the theories of the English jurist and utilitarian philosopher Jeremy Bentham. Bentham has tried to find out that there is an important similarity between humans and animals despite of differences. This approach, which leads to a change in the perspective of the period, has also impact on the legal sense. For example, in Britain, the Animal Protection Act dated 1911 sets out that "beating, kicking, exploiting, overloading an animal ruthlessly, making it overfatigue, extreme fury or intimidate or torturing and agonizing it without the unnecessary ground" were counted as an offense (Francione, 2008: 55-58). It should be noted that the greatest contribution to the ideas concerning animals in the field of modern science came from the studies of Charles Darwin in the 19th century. Based on observations, Darwin concluded that many animals have general concepts, a kind of reasoning ability, a foundation of moral sensitivity, and complex feelings (Degrazia, 2006: 18). For Darwin, the animals looked down on can feel the pleasure and pain, happiness and suffering explicitly just like people. Some observers also said that even insects play together with their offspring (Darwin, 1989: 27-28). According to the philosophy of "respect for life" which Albert Schweitzer was a pioneer, it is wrong to remain in silence while we are experiencing situations with full of suffering that we cannot completely feel but are guessing. The philosophy of respect for life advocates that we need to "help them as much as we can, and we must be united", so that the living beings can relieve this horror and end their suffering to a great extent (Schweitzer, 1989: 37). 
Beyond all these approaches, the opinions of the Australian philosopher Peter Singer's Animal Liberation and the American philosopher Tom Regan's The Case for Animal Rights work discovered more humanitarian thoughts about the moral statues of animals and our obligations to animals. Within this framework, Singer argued that the principle of treating equally should be applied to all animals that have the ability to feel by rejecting the speciesism. Singer, however, defended that animal interests should be more considered than they are now and stated that animals would continue to be used for human purposes. Tom Regan stated that animals have ethical rights and animal abuse should be eliminated without regard to the consequences of that. This theory of Regan includes all living beings that are the subject of a life 1 . Regan indicated that all normal mammals over a year or older (Francione, 2008: 38-40) can be included in this context

Perhaps the most valid and humanitarian of these opinions suggested on animal rights is rejection of speciesism proposed by Regan. It would not be wrong to express this belief in this framework: "Any flaw that we can think of making animals down from us can also be seen in some groups of people. Hence, if the race is not an excuse for human slavery, the species alone is not a moral benchmark to exclude animals" (Francione, 2008: 34). Showing a different attitude will not make us different from the individuals we call racist, sexist (Singer, 2005a: 22).

Unlike these thesis, which try to adopt the idea that animals have the right to life without pain, billions of animals are tortured, imprisoned or killed for the sake of human interests. The conditions in which these living creatures are correspond to a slavery-like understanding that we can use for all of human interests and desires (Cavalieri, 2005: 39). Therefore, we should not accept the circumstances and situations that we cannot accept when they are human, even if the animals are in question. Because it should not be ignored that respect for animals is not a matter of politeness, but of the matter of justice (Regan, 2005: 34).

\section{Animal Welfare and Animal Rights Opinion}

If an assessment is made within the context of the approaches addressed, it is seen that there are quite different opinions regarding the moral status of animals. This situation is fed from two sources. The first one is to advocate the recognition of the same rights entitled to human for animals in the animal rights approach, and the second is that animal protection organizations use animal rights expression to describe any kind of posture without discrimination (Francione, 2008: 37). In fact, all these differences lead us to two basic concepts: "Animal Welfare" and "Animal Rights".

Supporter of animal welfare defend that there must be strong laws requiring humanitarian treatment to prevent persecution. The ASPCA (American Society for the Prevention of Cruelty to Animals) was founded by those whose opinions are based on

${ }^{1}$ Regan has defined those who is the subject of a life as" a living creature who has beliefs and desires; a sensation of the future including perception, memory and future of oneself; an emotional life with feelings of pleasure and pain; Preference and prosperity interests; the ability to initiate action in the direction of its desires and goals; as individuals with a psychophysical identity over time and an individual well-being in the sense that they reasonably deal with others with their life based on their experiment in an independent way of their benefit" (Francione, 2008: 38). 
this approach. In addition to this view, defenders of animal rights are also opposed to any use of animals by humans. Defenders of animal rights state that when people need to be treated it must be done without using animals. Defenders of this view are against the use of animals in circuses, zoos, agricultural lands, hunting, and scientific experiments including rodeos. PETA (People for the Ethical Treatment of Animals) and HSUS (The Humane Society of the United States) are organizations based on this approach (Sunstein, 2000: 4-5). Animal welfare theories accept that animals have their own interest and allow the interests of animals to be transformed into trade as long as these interests are for the interests of humans. Animal rights approach advocates the idea that animals, like humans, are inevitable interests that cannot be transformed into trade so that others gain advantages. It therefore means that animals cannot be used for food, clothing, entertainment or experimentation purposes. Also, animal welfare allows such benefits as long as humanitarian methods are concerned (www.animalliberationfront.com).

Historically, animal welfare groups have sought to improve the place of animals in the society. These people have struggled against the concepts that animals don't have souls and that they are worthless in moral meaning. The animal rights movement has emerged as an alternative to the reformist animal welfare (www.animalliberationfront.com). It was understood after comparative assessment that the most consistent and correct theory to be used in advocating animal rights is the "Theory of Rights", which treats every living creature as an entity with innate rights. According to this view, all kinds of conscious and sensitive creatures, whatever intelligence levels, abilities and race are all have inherent, basic rights (Tuna,1991: 76).

Although it is generally stated that animals have a less respectful attitude towards other societies, the birth of the idea of contemporary animal rights has occurred in the West. In the 19th century, the first animal-rights movement began to oppose the use of anesthetized animals in scientific research in England (Degrazia, 2006: 20). The animal rights movement is against animal use in experiments. Because it is not only contrary to the rules of moral rules and justice; it is also harmful to the environment and health. The ecological equilibrium is disturbed by the fact that these animals are either removed from their natural habitat or reproduced artificially in order to be used as guinea pigs. The animal rights movement is opposed to the all kind of torture such as hunting, fur farming, and use of animals for fun, which is in conflict with moral and justice understanding and has huge ecological damages (Tuna, 1991: 70).

That the animal rights movement turned into an organizational base was initiated by establishing the British Hunt Saboteurs Association (www.huntsabs.org.uk/) in 1963, Greenpeace in 1971 and PETA-(People for The Ethical Treaty Of Animals) in 1980 (Degrazia, 2006: 21-22). In addition, the first success against experiments on animals in the United States was provided by a campaign launched against experiments in which the sexual behavior of cats that were disabled at the American Museum of Natural History in 1976-1977. Henry Spira, who designed and conducted this campaign, has turned to bigger targets and has succeeded in enabling the cosmetic industry to test products without using animals or with suffering less animal much less (Singer, 2005a: 23). The 
Universal Declaration of Animal Rights, proclaimed on October 15, 19782, has made a breakthrough in this field. Thanks to the established institutions and awareness, people remain no longer in silence against massacres that were made even in festivals ${ }^{3}$ for years ago and are aware that any kind of violence can be no longer acceptable, and NGOs have been established in the field of struggle for the animal rights at the international level (Tosun, 2003: 244). However, although the violations made explicitly against animals and their right to live painlessly through the activities of the animal rights movement has diminished compared to the past, they are still happening today. It is also necessary to take into account the psychological and administrative dimension of these violations, which are carried out by suggesting scientific or commercial concerns. The most important victims of administrative violations are street animals called "stray".

\section{Major Areas Where Animal Rights are Violated}

In the shadow of the developments and discussions in the historical process, on

2 In accordance with Universal Declaration of Animal Rights solemnly proclaimed in Paris on 15 October 1978 at the UNESCO headquarters (https://constitutii.files.wordpress.com/2016/06/file-id-607.pdf); All animals are born with an equal claim on life and the same rights to existence. 2. All animals are entitled to respect. Man as an animal species shall not arrogate to himself the right to exterminate or inhumanely exploit other animals. It is his duty to use his knowledge for the welfare of animals. All animals have the right to the attention, care and protection of man. 3. No animal shall be ill-treated or shall be subject to cruel acts. If an animal has to be killed, this must be instantaneous and without distress. 4. All wild animals have the right to liberty in their natural environment, whether land, air or water, and should be allowed to procreate. Deprivation of freedom, even for educational purposes, is an infringement of this right. 5. Animals of species living traditionally in a human environment have the right to live and grow at the rhythm and under the conditions of life and freedom peculiar to their species. 6. All companion animals have the right to complete their natural life span. Abandonment of an animal is a cruel and degrading act. 7. All working animals are entitled to a reasonable limitation of the duration and intensity of their work, to the necessary nourishment, and to rest. 8. Animal experimentation involving physical or psychological suffering is incompatible with the rights of animals whether it be for scientific, medical, commercial, or any other form of research. Replacement methods must be used and developed. 9. Where animals are used in the food industry, they shall be reared, transported, lair aged and killed without the infliction of suffering. 10. - No animal shall be exploited for the amusement of man, Exhibitions and spectacles involving animals are incompatible with their dignity. 11. Any act involving the wanton killing of an animal is biocide, that is, a crime against life. 12. Any act involving mass killing of wild animals is genocide, that is, a crime against the species.13. Dead animals shall be treated with respect. Scenes of violence involving animals shall be banned from cinema and television, except for humane education. 14. Representatives of movements that defend animal rights should have an effective voice at all levels of government. The rights of animals, like human rights, should enjoy the protection of law.

3 "From 1934 to 1988, on every Labor Day, there was a festival of hitting a live animal in the small Hegins town of Pennsylvania in the United States. Participants came from all over the world to participate in the event. In the annual event, about five thousand pigeons which were released individually from the cages were targets to participants. Most of the birds - more than three out of four of the birds according to the Animals Fund - were injured but did not die immediately. Some were left in the shooting range until each competitor completed his shot, while others escaped to the nearby tree where they would gradually die because of their injuries. After the completion of each shot, the little children was collecting the wounded birds and were jumping on them, cutting off their heads, hitting them rapidly on the edge of the barrels, or dipping them in barrels for drowning in other dying or dead pigeons. Both the shooters and the children publicly performed these actions publicly, with thousands of spectators paying to sit and eat and drink on the wooden stands and applaud the children." (Degrazia, 2006: 27-28). 
the one hand the opinion that animals have rights is adopted and efforts are made to give the animals the values they deserve; on the other hand, it is seen that these rights are violated in many fields from scientific researches to commercials, to funny spores in daily life.

\subsection{Fur Trade and Hunting}

For many people, clothes and goods made from fur, which are the symbol of your wealth, constitute one of the most injured areas for people who are sensitive to animal rights violations. However, in consumer societies, expensive and difficult to find furs are a means of gaining social status for some people since they are valued according to the goods they use (Tuna, 1991: 14). For this trade, "every year, forty million animals in the world are killed to make fur coats and other clothing from their peltry. About thirty million of these animals, including mink, fox, chinchillas and raccoons are grown in 'fur farms'. Fur animals grown on farms are killed by gas, broken necks, or are poisoned and electrocuted by anal or genital tract. In addition, about ten million animals are hunted each year with traps for their furs, except for those animals accidentally caught in traps" (Francione, 2008: 95). It is very difficult to estimate the number of Canadian seals killed each year. It is enough to discover the size of the count that thirty thousand monks brutally murdered on the first day of the massacre. In this massacre that has been going on for 350 years, $40 \%$ of the seals hunted for flesh and skin are flayed alive (www.hurriyet.com.tr). The dimension of the savagery and the severe of the pain have revealed that as Regan says, "the animal fur or his skin must be on the back of only the animal that is his true proprietor" (Regan, 2007: 184).

Hunting is another area where animal rights violations are experienced. It should not to consider the killing of animals who are staying on the migration route, who are defenseless during the breeding season, or who try to maintain their lives harmlessly in their wild environment despite the changing climatic conditions as a sportive activity. As a result of hunting on the pretext of such as sports or nutrition rather than natural reasons, only in Turkey many species such as Indian elephant, wild ass, Caucasian Ox, Asian Cheetah, Houbara Bustard, Darter, Mongolian Wild Horse, Anatolian Leopard, Asian Lion, Caspian Tiger, little bustard have become extinct (bursaobm.ogm.gov.tr). In similar cases, there are animal species that are endangered or completely extinct in many countries. This means that the ecological system is deteriorating. The story of the wolves 4 in Yellowstone National Park in the USA and the example of the sparrow massacre decided by Mao Zedong have summarized this situation in the most beautiful way.

However, in many countries hunting activities including whale and seal killings keep going on. In order to be able to talk about animal rights and to protect these rights in real terms, it is necessary to prohibit hunting except in cases of necessity. Because in case of the absence of human intervention natural selection works perfectly.

\footnotetext{
${ }^{4}$ In the 1920s, American officials decided to clean the national park from wolves, and Yellowstone National Park remained without wolf for the next 70 years. This situation threw off the entire natural balance of the park. In 1995, after long planning, it was decided to put the Canadian wolves again in the park, with this decision a revival in nature was experienced. With the decline in the number of deer in the park, many species of trees have been able to grow again (www.bbc.com/earth/). With the increase in the number and variety of trees, it has been observed that the behavior of many animals from birds to beavers, even the river in the park, changed positively.
} 


\subsection{Zoos \& Entertainment Sector}

The zoos that are launched in a beneficial manner are places that operate with intent to introduce animals to individuals, especially children, but in reality, they can only provide sick animals under stress, iron wire, stone and concrete (Yalçin, 2008: 60). These lives of the animals under stress in the zoo are a tragedy in itself. Because these animals are caught in natural habitats, reproduced in captive animal reproduction programs of zoos, or borrowed or purchased from other zoos. Most of the animals that are forced to travel long distances, usually in tight containers, are sick, wounded or dead when they arrive at their destination. The animals in the zoo are confined to barren cages, which do not provide any physical or mental stimulation. The zoo which is provided as Natural habitats are made up of trees with metal leaves, usually made of concrete form and plastic resin. Also, the places where animals spend most of their time apart from showroom areas are just cages that are even deprived of these arrangements. Many of these animals exhibit neurotic behavior. Animals that are aging or lost their interest in exhibition are sold to animal farms and their fate is unknown (Francione, 2008:88-90).

One of the places where animals are going through the greatest suffering is the circus. Apart from the conditions that are dismantled and taken away from their wild and natural environment and which do not conform to their nature, animals that have been exposed to extra torture and earned money from them have little chance of survival and to live (Yalçin, 2008: 60). Animals used in circuses are generally kept in small, barren cages that are large enough to stand on their feet and sleep. Large animals such as elephants are struck in the chain when they are not performing and often transported to long distances in freight wagons in extreme heat. Animal "trainers" often predominate over animals through fear and suffering, in order to make them physically or psychologically unusual tricks. Even in the United States, which is considered to be the pioneer of animal rights, there are zoos, circuses, carnivals, horse and dog racetracks, marine mammals' parks and rodeos. These animals used in the entertainment industry are sentenced to life imprisonment and to live in bad conditions for their whole life (Francione, 2008).

Also in the scope of recreational activities, marine mammals' demonstrations where dolphins, killer whales, seals, sea lions and other animals make "tricks" for audiences have been organized. Most of these animals caught in natural habitat are trained by methods based on psychological and physical pressure. In addition, when these animals which use echo-location method in order to navigate and communicate are confined in water tanks, pools or other places, their voices are reflected back to themselves and they die in much shorter time than in natural habitat under heavy stress. For instance, nearly $80 \%$ of killer whales, which can live up to eighty years in their natural environment, usually die before they are eight years old in these villages (Francione, 2008: 93).

\subsection{Scientific Violation: Vivisection/Experiments on Animals}

Experiments on animals called vivisection are the area where animal rights are "scientifically" violated. Within the scope of the experiments, animals have been exposed to many kinds of maltreatment such as live cutting, burning, exposure to chemical substances and cancerous cells, breaking bones, removal of organs, poisoning, boiling (Tuna, 1991). Although nowadays, the medical world can make artificial skin, it is seen 
that these experiments are applied in many of the fields especially both cosmetics and cleaning sectors (Yalçın, 2008: 59). Animals are also used for testing nuclear and conventional weapons in aircraft, automobile and missile tests. These experiments, usually done without numbing the animal (Tuna, 1991: 50), are symbols of the great tragedy.

Experimental animals, unlike all other victimized animals, are animals who have been sentenced to torture for days and are "not even allowed to die" (Yalçın, 2008: 60). Besides, it is known that these animals are used not only in physical but also in psychological research. To exemplify, drug addiction is caused in these animals and the results are examined; practices such as mother-child separation to create depression; torture of mother and child together, imprisonment in steel cisterns, being unable to sleep in water for months on their feet, and so on have occurred. Taking into account the experiments conducted in this area, it is revealed that for the investigation of the sleep rhythms of humans, the kittens are kept awake under torture for up to 70 days (Sungurbey, 1992: 26), baby monkeys are raised by being separated from their mothers or being in complete isolation or with "deputy" mothers designed to hurt them when they want to hug. In the "learned helplessness" experiments carried out by Seligman and his colleagues, It is reported that dogs are given heavy, long-lasting electricity and burned, dogs who are unable to escape despite the pain give up to get rid of the pain (Francione, 2008: 115).

When the literature on experiments on animals is searched, we have seen these striking examples: In the LD50 test, a product such as lipstick is forcibly fed to animals in order to determine whether or not the death case will occur. These and similar tests constitute a secret history behind the labels "hazardous to bealth or fatal" on the boxes of products such as brake fluids, household oils and solutions used in the industry (Regan, 2005: 248). In the Draize test where researchers put chemical substances into the eyes of animals in order to examine eye tissue damage (Francione, 2008: 122), potentially toxic substances are applied directly to the eyes of rabbits with consciousness and their eyes are severely damaged (Degrazia, 2006: 171). These tests often use albino European rabbits whose tears are much less than those of other animals, and it is also known that they are tied with a rope on the workbench in order to prevent animals from escaping or rubbing their eyes. Animals with blind eyes as a result of the test are either killed or used in other experiments ${ }^{5}$ (Francione, 2008: 122).

In the reference book named Clinical Toxicology of Commercial Products, there are data acquired through many animal studies on how toxic the hundreds of commercial products are. Many scientists and doctors have criticized these tests on the grounds that the results don't apply to human, and have stated that test results fail to lead to human treatments since they cannot be used to "predict the toxicity in people taking these substances" or "to select the treatment routes." In addition, it has been stated that the poisoning cases coming to the emergency services never apply to experimental data such as Draize test and doctors apply the experimental data gathered through case reports, clinical experiences and clinical trials on humans while determining the most appropriate

${ }^{5} \mathrm{~A}$ list of companies that use and do not use animals in experiments, especially in the cosmetics sector, can be found at http://features.peta.org/cruelty-free-company-search/index.aspx prepared by PETA. Current policies of these companies are updated twice a year (www.mediapeta.com/peta/, 10.04.2017). 
treatment for the patients (Singer, 2005b: 99-100). Besides, it is stated that certain medical inventions relating to animal use are carried out despite animal use but not the reason of animal use. For instance, the invention of childhood paralytic vaccination was delayed because of the negative consequences of bypassing on animals (Francione, 2008: 110). Similarly, it is known that animals are also used in contemporary cancer research, animals are injected with cancer-causing viruses, but none of the experiments on animals can be applied to humans since no tumor of the animal has developed close to the cancer tumor in the human body (Sungurbey, 1992: 26). In the United States, the rate of age-adjusted cancer has climbed steadily, even though in 1971 it declared "War on Cancer" and spent billions of dollars on cancer research. According to Dr. Irwin D. Bross who is a director of Roswell Park Memorial Cancer Research Institute Biostatistics, "inconsistent experiments on animals have often delayed and sabotaged the progression of war on cancer; there has been no significant progress in the prevention or treatment of human cancers." (www.whale.to/cancer/; Francione, 2008: 109-110). In addition, toxicologists stated that some medicines ${ }^{6}$ may lead to human deaths after they are put on the market, even though they haven't caused any adverse effects on the animals during the experimental period (Singer, 2005b: 101).

Nowadays, there are many "in vitro" methods which are valid, reproducible and usually cost-effective rather than even that in experiments on animals. It is possible to use human cell and tissue cultures obtained from surgeries in tests. Bacterial cultures give proper results when tested for hereditary disorders. Chemistry and cosmetic products can also be tested on artificial skin. Besides, advanced computers allow the pharmacological effects of new substances to be predicted in advance (Gericke, 2008: 31). Thus, excuses for the use of many field animals are coming to an end.

\subsection{Animal Owners, Petshops and Local Governments}

Another area where animal rights violations are often seen is that animal owners mistreat animals on the basis of sense of ownership. These animals, which are instantly enthusiastically owned, are then exposed to various kinds of torture by some individuals. Surprisingly, therefore, animal rights must also be protected against animal owners (Yalçın, 2008: 58). It is discovered especially through the social media that some of the possessed animal are being sexually, physically and psychologically abused by their own owners, sometimes they are tied in a place without food and water, and they are in the center of violence. In this point, to illustrate, in Turkey cat killed by its owner in various torture, news about the dog who was tethered behind the car was being dragged, and more are imprinted on the memories. In addition, the number of animals abandoned to shelter or streets is also quite high.

\footnotetext{
${ }^{6}$ For example, the drug called Opren has been introduced as a "miracle drug" in the treatment of joint inflammation after it has passed all the usual animal tests; But sales of the drug was banned in the United Kingdom after 61 deaths and over 3500 adverse reactions. Animal testing can lead to damage to humans, as well as the inability to use some valuable products that are dangerous for animals but harmless to humans. For example, insulin that causes malformations in baby rabbits and mice does not cause such an effect in humans. Morphine, which calms people down, also causes extreme excitement and enthusiasm in mice. If penicillin was assessed according to the toxicity of the guinea pigs, it was stated that it could never be used in humans. (Singer, 2005b: 101).
} 
Another violation to which pets are exposed is pet shops which we call pets store. About five hundred thousand dogs are being sold in pet shops per year; many of them are kept in bad conditions and come from breeding farms called puppy dog factories. Female dogs are constantly breeding on these farms, and when they reach a state where efficiency cannot be obtained, they are killed. Puppies at 4-8 weeks are taken from their mothers and sent to pet shops or pet wholesalers through trucks, caravans or airplanes. About half of the dogs reproduced in puppy dogs factories die because of unhealthy conditions or during transplantation (Francione, 2008: 169-170). One of the biggest partners in this bloody market is Turkey. Especially the iron curtain countries with poor economic conditions consider Turkey as an additional source of income and find ways to introduce kittens, dogs and birds into the country in various ways. However, the cases against the persons captured at the border gates are imposed a fine because of the fact that the crime is not organized. Especially puppies among which are brought off the back of a lorry are sold for as high as 500-1,500 \$, most of them are abandoned or reproduced in some way and become "purebred" stray dogs. "That St. Bernard purebred dogs living in the Swiss Alps become a street dog at 45 degrees in Marmaris is an example of this vicious circle" (Şenpolat, 2008: 40-42). The inadequacy of living conditions of animals in pet shops and the use of fake veterinary stamp are also common (www.petshopgercegi.com). Nevertheless, large amounts of money in this sector are not only attracted to people, but also animals are forgotten that they are living things, and people are the actors of all kinds of irregularities.

One of the most intense and obviously violent areas is the streets. Every day, there are reports of animals losing their lives for many reasons such as traffic accidents, hunger and disease in the media. In addition to this, violence-prone individuals, who are not trained properly, constitute a great danger to animals (Yalçın, 2008: 58). Street animals forced to spend the rest of their lives in concrete streets due to urbanization, struggle both to cope with starvation and seasonal conditions and are exposed to abuse originating from human. It is known that the cases of poisoning, physical and sexual assault are intensively experienced when analyzing specific to Turkey. In addition, many negligence and violation have occurred in terms of administration. In this context, many municipalities are at the top of the list in the poisoning and shooting with firearms although it is statutory obligation to create and spread campaigns of "castration", "vaccination" and "live". Sometimes municipalities perform these actions directly and sometimes indirectly by leaving animals away from the city center. They are abandoned to settlements such as towns, villages, or mountainsides or forestlands and are left to their own fate. Because of the individuals and institutions that see killing as a solution for struggling with the animal population, many animals, such as cats, dogs, and birds, which must survive in their natural habitat, often die in pain. When the articles and news on this subject are examined, it is seen that a substance called striknin is generally used. It is also stated in the related research that many animals, which are possessed or stray animal, have been subjected to sexual assault by people and to various kinds of torture. Another common example is the fact that the animal shelters that are supposed to be in the provisional nursing home are the same as concentration camp where animals are deprived of feeding, treatment and care. It would be a correct assumption to say that the actions focus on extinction of the species although the type of violence, the size, and the extent to 
which it is done by who differs.

In many European countries, which take important steps in the protection and defense of animal rights, putting animal to sleep is being carried out widely. This action does not take place in the form of the end of life for the animals who are only sick at the advanced stage under the euthanasia with the consent of their owners. Although in some regions, there is a special organization under the name of "Animal Protection Police"7 which can be taken as an example, it is also seen a practice that non-owned animals are put to sleep after a while. In this application, a dog left in a shelter loses its chances of survival if it is not owned within 72 hours. When numerically stated by shelter volunteers, it is stated that every year only 11 million animals have been killed in shelters in the US (www.fatihbelediyesiyedikulehayvanbarinagi.com).

\section{Conclusion}

Although nearly forty years have passed since the Universal Declaration of Animal Rights was proclaimed, it cannot be said that all countries and people have the same sacrifice in the protection of animal rights. While some countries legally guarantee the lives of animals that are the main equilibrium elements of ecology, some countries are insensitive to massacres despite the reactions of non-governmental organizations.

It is known that animals whose right to life is violated in many areas, from fur trade to hunting, from scientific experiments to entertainment sector, animal rights are also exposed to extortion by individuals and institutions. For instance, it is necessary to mention that in recent years, a toucan bird in Costa Rica was attacked and its beak was lost as a result of human-derived violence and reactions of the people around the world made an overwhelming impression. Many people and companies were mobilized so that this bird called as Grecia would maintain its life and it enabled it to survive with the prosthetic beak. Similarly, in Turkey, the treatment of a cat called as Umut (Hope in English) whose frontal legs were cut and abandoned on the roadside was made by sensitive people and its violence exposed collected the great reaction. In fact, these events have become one of the first things that come to mind when animal rights are mentioned in recent years. However, unity, solidarity and sensitivity provided in the case of Grecia and Umut do not always result in the same way. The most tragic example in this regard is the Yulin Festival (!), which is not prohibited on the grounds that it is traditional despite the intense reactions of many countries. In China, hundreds of dogs are often boiled or savaged alive, and people think that eating cat and dog meats is keeping their traditions. Similar practices continue in many Far Eastern countries, and especially in China and South Korea, the struggle to rescue pets such as cats and dogs from meat markets and slaughter houses is being tried to occur only with individual efforts. In addition, footages of sacrificing an animal in Muslim countries are being reacted by many people and the conditions of the animals in the meat and milk production farms are being discussed all over the world.

\footnotetext{
7 Animal protection officers serving in some states and in some parts of the world are charged with assisting street animals in need of help and possessed animals, and are responsible for identifying those who torture animals, kill them and for punishing them before the law, as well as supervise animal owners. For example: Houston SPCA (http://gazetedokuzeylul.com/?p=894).
} 
It is seen that the part of all the living things in the ecological system are overlooked because of all these violations and abuses occurred. Particularly human-derived forest fires cause both the disappearance of the flora fauna and lead to kill numerous creatures that continue their lives in the forests by burning and also destroy many trees in hectares. As a result, it is necessary to note that the struggle for rights of animals, which is a weak element in living species and often ignored, continues against people and institutions. However, whether or not this struggle will win a victory still depends on the initiatives of people and institutions.

\section{References}

Cavalieri P.(2005). "For an Expanded Theory of Human Rights", (Translated by Saliha Nilüfer), Birikim Journal, Issue 195, p. 39.

Darwin C. (1989), "Comparison of The Mental Powers of Man and The Lower Animals", Animal Rights and Human Obligations, Ed. Tom Regan-Peter Singer, New Jersey: Prentice Hall, Englewood Cliffs.

Degrazia, D. (2006). Animal Rights, (Translated by Hakan Gur), Ankara: Dost Bookstore Publications.

Francione, G. L. (2008). Introduction to Animal Rights, (Translated by Renan Akman-Elçin Gen), Istanbul: İletişim Publications.

Gericke, C. (2008). "Introduction to Animal Experiments Problems", Istanbul Bar Association Journal: Legal Approach to Animal Rights-Special Issue, Istanbul: Can Printing.

Günerken Ö. (2014). “Animal Protection Police”; http://gazetedokuzeylul.com/?p=894 (19.06.2017)

Regan, T. (2005). "Basic Arguments for Animal Rights" (Translated by Elçin Gen), Birikim Journal, Issue 195, p. 34.

Regan, T. (2007). Empty Cages,( Translated by. Serpil Çağlayan), İstanbul:İletişim Publications.

Schweitzer, A. (1989). "The Ethic of Reverence for Life", Animal Rights and Human Obligations, Ed. Tom Regan-Peter Singer, New Jersey: Prentice Hall, Englewood Cliffs.

Singer, P. (2005a). "30th Year of Animal Liberation", (Translated by Hayrullah Doğan), Birikim Journal, Say1 195.

Singer, P. (2005b). Animal Liberation, (Translated by Hayrullah Doğan), İstanbul:Ayrıntı Publications.

Sunstein, C. R. (2000). "Animal Welfare and Animal Rights", Animal Rights, Ed. Cass R. Sunstein-Martha C. Nussbaum, New York: Oxford University Press.

Şenpolat, A. K. (2008). "How much longer is Animal Torture covered by Misdemeanor Law?", Istanbul Bar Association Journal: Legal Approach to Animal Rights - Special Issue, Istanbul: Can Printing.

Tosun G. E. (2003). "Civil Society", Contemporary Public Administration- I, Editor Muhittin Acar- Hüseyin Özgür, Ankara: Nobel Publication Distribution.

Tuna,G. (1991). Animal Rights, Ankara: Herself Publication.

Yalçın, H. (2008). "Legal and Social Dimension of Animal Rights Violations", Istanbul Bar Association Magazine: Legal Approach to Animal Rights-Special Issue, Istanbul: Can Printing.

http://bursaobm.ogm.gov.tr/Documents/FikirBahcesi/16/tukenen_turler.pdf, (28.03.2017).

https://constitutii.files.wordpress.com/2016/06/file-id-607.pdf, (26.08.2017).

http://features.peta.org/cruelty-free-company-search/index.aspx, (10.04.2017).

http://www.animalliberationfront.com/ALFront/Actions-Turkey/alf_sss2.htm, (10.03.2017).

http://www.bbc.com/earth/story/20150416-the-truth-about-wolves, (05.08.2017).

http://www.fatihbelediyesiyedikulehayvanbarinagi.com/hakkimizda/gonulluler/gonullu-kosesi/amerika-dabir-barinak-yoneticisinin-mektubu/, (30.03.2017).

https://www.huntsabs.org.uk/, (17.03.2017).

http://www.hurriyet.com.tr/ciplak-ve-kanli-11222476, (28.03.2017).

http://www.mediapeta.com/peta/PDF/companiesdonttest.pdf.,(10.04.2017).

http://www.petshopgercegi.com/petshop-gercegi-grubu/, (02.02.2009).

http://www.whale.to/cancer/bross_h.html, (10.04.2017). 